\title{
Two endemic new species of Begonia (Begoniaceae) from Palawan, Philippines
}

\author{
L.M. Camangeg ${ }^{1}$, W. Cabanillas², M.N. Tamayo ${ }^{3}$, V.C. Mangussad ${ }^{1}$, \\ M.A.K. Pranada ${ }^{2}$ \& Y.P. Ang $^{2}$ \\ ${ }^{1}$ Palawan State University, College of Sciences, \\ BioPhysical Department, Brgy. Tiniguiban, \\ Puerto Princesa City, Palawan, 5300 Philippines \\ ${ }^{2}$ Philippine Taxonomic Initiative, Inc., Botanica Building, \\ El Nido, Palawan, 5313 Philippines \\ ypang@phtaxa.org \\ ${ }^{3}$ Department of Biology, College of Science, \\ University of the Philippines Baguio, \\ Governor Pack Road, Baguio City, 2600 Philippines
}

\begin{abstract}
On recent expeditions, two endemic new species of Begonia sect. Baryandra, Begonia obscuribracteata Y.P.Ang, Cabanillas \& M.N.Tamayo and Begonia tandikan Pranada, L.M.Camangeg, Cabanillas \& Y.P.Ang, were discovered and are hereby described and illustrated. Begonia obscuribracteata is similar to B. cabanillasii Y.P.Ang et al. in having suborbicular leaves that are adaxially hairy, five conspicuous wings on the ovary, and tepals that are hairy on the outside. However, it can be easily distinguished by features of its leaves, stipules, and bracts. A key to similar Begonia species with a conspicuous 5-winged ovary is provided. Begonia tandikan morphologically resembles B. beijnenii Y.P.Ang et al. but differs by having a broadly ovate (vs subrhomboid) lamina with a villous (vs glabrous) upper surface, shorter and wider stipules with aristate (vs cuspidate) apices, and minutely pilose (vs glabrous) bracts. Following IUCN guidelines, Begonia obscuribracteata is assessed as Endangered (EN) and Begonia tandikan as Critically Endangered (CR).
\end{abstract}

Keywords. Begonia beijnenii, Begonia cabanillasii, Begonia quinquealata, Cucurbitales, Malesia, taxonomy

\section{Introduction}

The province of Palawan is the largest island-province in the archipelagic Philippines based on land area. It is found on the Sunda Plate and has a different geological history compared to other Philippine islands (Revel, 2006). The unique geological history and biogeographical location of Palawan has led to many unique and endemic species. Palawan is also famously referred as the Philippines' Last Ecological Frontier (Revel, 2006) and, through the years, botanical expeditions have been conducted in this area of high biodiversity resulting in numerous discoveries and rediscoveries.

The species of Begonia L. sect. Baryandra A.DC. (De Candolle, 1859: 122), as currently understood, are generally rhizomatous herbs that lack an erect stem, 
have persistent stipules, boat-shaped bracts, staminate flowers with 4 free perianth segments, carpellate flowers with 4 (rarely 5) perianth segments, 3 equal or unequal wings on 2-3 locular ovary, bifid placenta in each locule, and a pendulous or recurved fruit at maturity (Rubite et al., 2013). The Philippines is known as a centre of diversity for this section with 70 species from the country described thus far. In Palawan, the majority of the known species are in Begonia sect. Baryandra (22 out of 25) while the remaining three belong to Begonia sect. Petermannia (Klotzsch) A.DC. The species of Begonia sect. Baryandra are distributed throughout Palawan, while those of Begonia sect. Petermannia are so far known only in the southern half of the island.

Continued exploration of botanically unexplored areas of this island has previously led to the discovery and description of three new species of Begonia, viz., B. cabanillasii Y.P.Ang et al., B. truncatifolia R.Bustam. et al. and B. beijnenii Y.P.Ang et al. (Ang et al., 2020a,b; Bustamante et al., 2020). All 25 known species of Begonia found in Palawan are endemic to the island except B. mindorensis Merr. (Merrill, 1911: 396) and B. nigritarum Steud. Begonia nigritarum has not previously been recorded from Palawan but in our surveys, we have observed that this species thrives across various localities in Southern Palawan.

Fieldwork to document noteworthy plants in the Municipality of Dumaran (Fig. 1), a largely botanically unexplored region of Palawan, led to the discovery of an unknown Begonia species characterised by having an ovary with six wings. This unknown Begonia closely resembles a small group of Begonia species from $B$. sect. Baryandra which possesses five conspicuous ovary wings, namely B. cabanillasii, $B$. suborbiculata Merr., and B. quinquealata C.I Peng et al. (Merrill, 1911; Hughes et al., 2018). The character of bearing more than three ovary wings within Begonia sect. Baryandra is unique to the island of Palawan. Further examination of the Dumaran specimen revealed distinct morphological attributes that distinguish it from these other species. The new species is named Begonia obscuribracteata Y.P.Ang, Cabanillas \& M.N.Tamayo.

While conducting a plant taxonomic inventory within the vicinity of Mt Pulgar, Puerto Princesa City (Fig. 1), Palawan, an unknown species of Begonia with mottled leaves was encountered along a nearby body of water. With its distinctive morphology, it was concluded that it is undescribed, though the species is closely allied to the other 2-locular Begonia species of Palawan, especially B. beijnenii. The new species is named Begonia tandikan Pranada, L.Camangeg, Cabanillas \& Y.P.Ang.

The discovery of these species highlights the uniqueness and rich diversity of Begonia on the island of Palawan. It also suggests that further botanical expeditions on the island will lead to the discovery of more new plant species.

\section{Materials and methods}

At least eight individuals of each species were examined during multiple field surveys conducted to document and monitor the populations. Measurements were taken with a vernier caliper or measuring tape in situ. Additional measurements were obtained from 


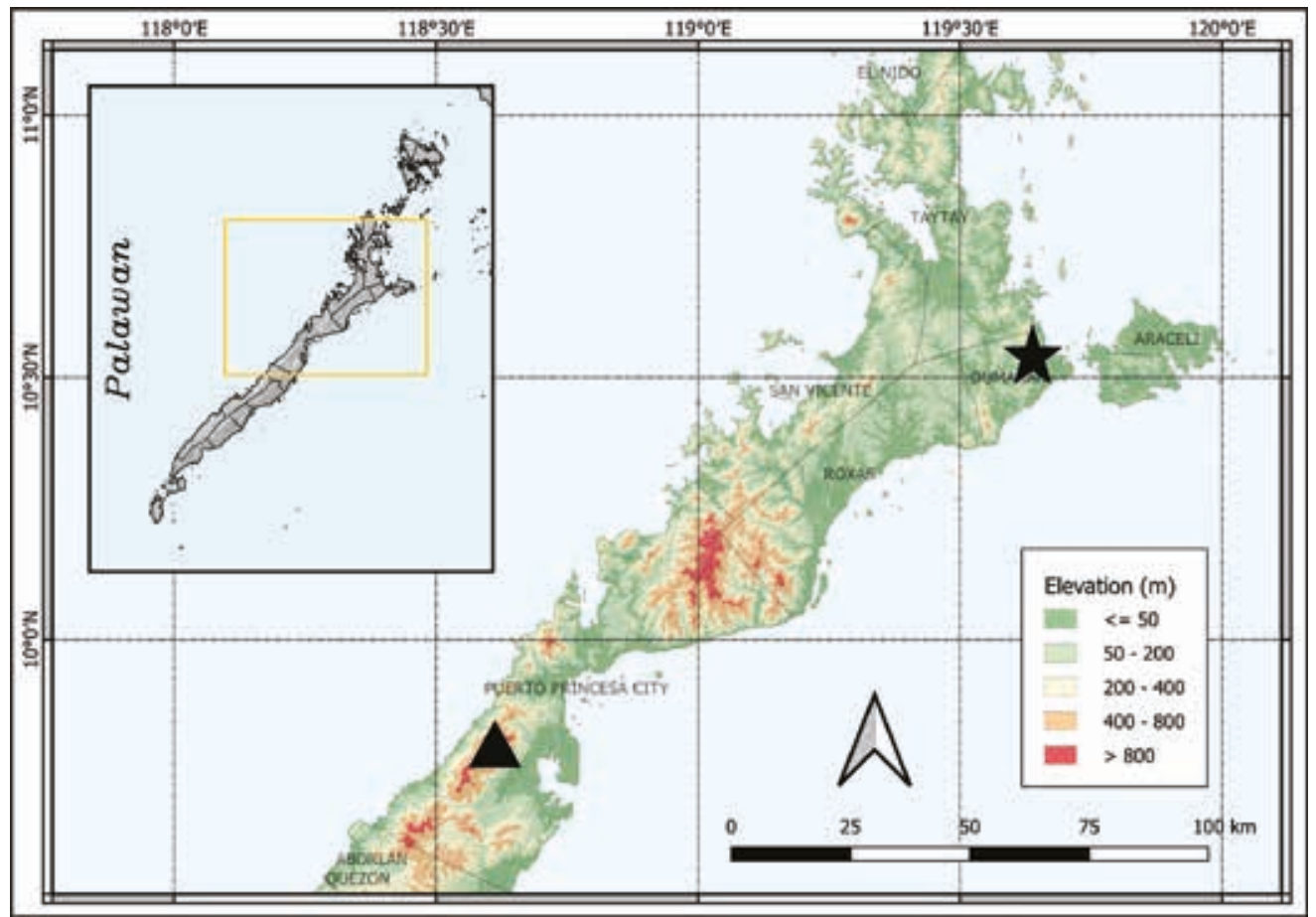

Fig. 1. Distribution map of Begonia obscuribracteata (star) and B. tandikan (triangle).

the specimens and from close-up photographs with scales of the fresh material. All collections were made under the Gratuitous Permit (GP) number 2018-28 (R1) issued by the Palawan Council for Sustainable Development Staff institution. Comparisons to protologues and herbarium specimens of similar Begonia species were conducted. The distribution map was prepared using QGIS v. 3.12 București (QGIS Development Team, 2020). Herbarium specimens were prepared using standard protocols.

\section{Taxonomy}

1. Begonia obscuribracteata Y.P.Ang, Cabanillas \& M.N.Tamayo, sp. nov. (§ Baryandra)

Begonia obscuribracteata is distinctive among Philippine species by having an ovary with 6 wings. It is similar to Begonia cabanillasii which also has suborbicular leaves that are adaxially hairy, bearing at least 5 conspicuous wings on the ovary, and flowers with tepals that are hairy outside. However, it can be distinguished from Begonia cabanillasii in its leaves adaxially red to white hirsute (vs white pilose), abaxially hirsute with indumentum $0.5 \mathrm{~mm}$ long (vs appressed hirsute on veins and sparsely puberulous on interveins, indumentum 1-2.5 mm long), comparatively smaller bracts at c. $2.5 \times 1.5 \mathrm{~mm}($ vs $4-5 \times 2-3 \mathrm{~mm})$, triangular stipules (vs lanceolate), shallowly keeled (vs strongly), abaxially tomentose (vs white pilose) with an apiculate apex (vs 
aristate), tip c. $1 \mathrm{~mm}$ long (vs 6-7 mm). Detailed morphological differences between the species are presented in Table 1. - TYPE: Philippines, Palawan Island, Brgy. Sta. Teresita, Municipality of Dumaran, 50-300 m, 14 September 2020, L.M. Camangeg \& W.P. Cabanillas PTI-5 (holotype PNH; isotypes FEUH, PPC). (Fig. 2-4)

Herb, lithophytic, monoecious, rhizomatous. Rhizome creeping, c. $6 \mathrm{~cm}$ long, 3-4 $\mathrm{mm}$ in diam., internodes c. $2.5-6 \mathrm{~mm}$ long. Stipules persistent, triangular, c. $10 \times 7$ $\mathrm{mm}$, shallowly keeled, margins entire, apex apiculate with tip c. $1 \mathrm{~mm}$ long, adaxially glabrous, abaxially white tomentose (hairs c. $2 \mathrm{~mm}$ long). Leaves alternate; petiole terete, maroon, white to red tomentose (hairs $0.5-3 \mathrm{~mm}$ ), $2.5-6.9 \mathrm{~cm}$ long, 2-3 mm in diam.; lamina basifixed, suborbicular to broadly ovate, asymmetrical, $6.2-7.6 \times$ 6-6.5 cm, broadside $3.5-5.5 \mathrm{~cm}$ wide, base shallowly cordate to cordate, sinus sometimes overlapping slightly, apex rounded to acute, margins crenate, shallowly undulating, ciliate (hairs $0.5 \mathrm{~mm}$ long), non-glossy, adaxial surface citrine, red to white hirsute (hairs 1-2.5 mm long), abaxially red hirsute, trichomes slightly more concentrated on veins (hairs c. $0.5 \mathrm{~mm}$ long), venation palmate, c. 8 veins, abaxially raised, branching dichotomously or nearly so, tertiary veins reticulate. Inflorescences axillary, protandrous, cymosely branching panicles, 7.3-8.4 cm long; peduncle 6.7-11 $\mathrm{cm}$ long, red, sparsely red pilose, branching up to 3 times. Bracts red, triangularovate, apex acute, caducous, red hirsute, margins fimbriate; lowest bracts c. $2.5 \times 1.5$ mm. Staminate flower: pedicel 1.4-2.1 cm long, sparsely red hirsute; tepals 4, pale pink, outer 2 widely ovate to suborbicular, apex rounded, abaxially red hirsute (hairs $0.5-1 \mathrm{~mm}), 8-10 \times 6-11 \mathrm{~mm}$, inner 2 narrowly to broadly obovate, glabrous, apex slightly retuse, 9-10 × 3-5 mm; androecium zygomorphic, c. $4 \mathrm{~mm}$ wide, stamens 24-28, 2-2.5 mm long, filaments free, anthers yellow, c. $1 \mathrm{~mm}$ long, oblong-elliptic, slits lateral, connective extended to apex and bluntly protruding. Pistillate flower: pedicel 1.6-1.8 cm long, sparsely red hirsute, tepals 4, pale pink, outer 2 widely ovate to orbicular, apex rounded, 7.5-11 × 7.5-11 mm, abaxially red hirsute (hairs 0.5-1 $\mathrm{mm}$ long), inner 2 narrowly to broadly obovate, apex rounded, 7-10 $\times 3-4.5 \mathrm{~mm}$, glabrous; ovary pinkish red, sporadically and sparsely red hirsute (hairs 1-2.5 mm long), trigonous-ellipsoidal, locules 2, one bifid placenta per locule, 6-7 mm long, 2-3 mm thick (wings excluded), wings 6 , largest wing lunate, markedly cucullate, distally truncated, proximally rounded, margins red fimbriate, c. $5 \mathrm{~mm}$ wide, lateral wings narrowly oblong, slightly increasing in width towards apex, distally bluntly truncated, margins fimbriate, c. $2 \mathrm{~mm}$ wide, 2 wings running between the largest wing and the lateral wings, narrowly crescent-shaped, margins fimbriate, c. $2 \mathrm{~mm}$ wide, a much narrower wing runs between the lateral wings, margins red fimbriate, c. $1 \mathrm{~mm}$ wide; styles 3, shortly fused at base, c. $2.5 \mathrm{~mm}$ long; stigma spirally twisted and papillose all around. Fruit pendent, recurved such that the largest wing faces down, 2 lateral wings slightly cucullate, forming a splash cup; the sixth wing runs down the middle and divides the splash cups into 2 basins.

Distribution and ecology. Begonia obscuribracteata is endemic to the Municipality of Dumaran. It grows in a mixed dipterocarp forest, in deep shade on rocks near a water body, at an altitude of about $300 \mathrm{~m}$. 
Table 1. Comparison of B. obscuribracteata with B. quinquealata and B. cabanillasii.

\begin{tabular}{llll}
\hline Character & $\begin{array}{l}\text { B. obscuribracteata } \\
\text { (Fig. 2-4) }\end{array}$ & B. quinquealata & B. cabanillasii
\end{tabular}

\section{Rhizome}

Length $(\mathrm{cm})$

c. 6

$>40$

c. 5

Internodes (mm)

2.5-6

15-50

2-4

Stipules

Shape

Triangular

Triangular

Lanceolate

Dimension (mm)

c. $10 \times 7$

$6-10 \times 4-8$

$11-14 \times 6-7$

Abaxial vestiture

Shallowly keeled, white tomentose

Strongly keeled, densely hirsute

Strongly keeled,

Apex

Apiculate

Aristate white pilose

Apex length (mm)

c. 1

3-5

Aristate

Leaves

Dimension (cm)

$6.2-7.6 \times 6-6.5$

$6.5-10.2 \times 4.7-7.8$

$6.5-13 \times 6.5-12.8$

Adaxial vestiture

Red to white hirsute, $1-2.5 \mathrm{~mm}$ long

Densely hirsute, $\mathrm{c}$. $2.5 \mathrm{~mm}$ long

White pilose, 2-2.5

Abaxial vestiture

Red hirsute, trichomes slightly more concentrated on veins (c. $0.5 \mathrm{~mm}$ long)

Hirsute on all veins mm long

Sparsely appressed red hirsute (1-2 mm long), between veins sparsely red puberulous (1-2 $\mathrm{mm}$ long)

\section{Inflorescence}

Bract shape

Triangular-ovate

Ovate to lanceolate

Lanceolate

Bract dimension

c. $2.5 \times 1.5$

$3-4 \times 1.5-2.5$

$4-5 \times 2-3$

(mm)

\section{Staminate flower}

Pedicel length $(\mathrm{cm})$

$1.4-2.1$

$0.5-0.6$

$1.5-2.5$

Stamen count

24-28

25-30

$35-45$

\section{Pistillate flower}

Pedicel length $(\mathrm{cm})$

\section{$1.6-1.8$}

$0.5-0.8$

$1-1.5$

Ovary size (wings excluded)

6-7 mm long, 2-3 mm thick

c. $7 \mathrm{~mm}$ long, $4 \mathrm{~mm}$ thick

7-8 mm long, 3-4 mm thick

Wings

$$
6
$$

5

5

Largest wing

Cucullate, c. $5 \mathrm{~mm}$ wide

Cucullate, c. $5 \mathrm{~mm}$ wide

Cucullate, 6- $8 \mathrm{~mm}$ wide 


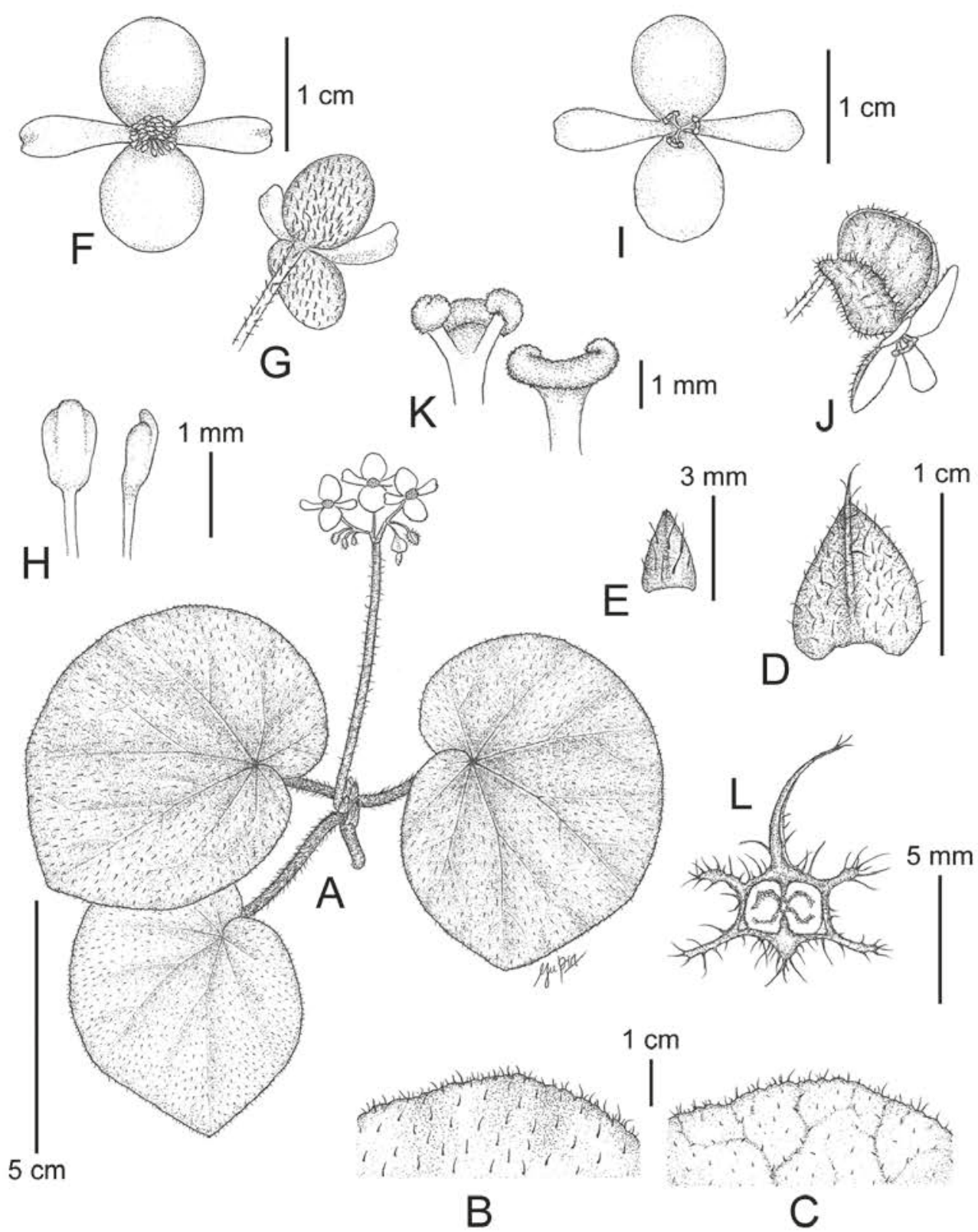

Fig. 2. Begonia obscuribracteata Y.P.Ang, Cabanillas \& M.N.Tamayo. A. Habit. B, C. Close up of leaf adaxial and abaxial surfaces respectively. D. Stipule abaxial side. E. Bract abaxial side. F, G. Staminate flower face and back view respectively. H. Stamen top and side view respectively. I. Pistillate flower face view. J. Pistillate flower side view showing ovary. K. Style front and back view. L. Ovary cross section. Drawn by Y.P. Ang. 


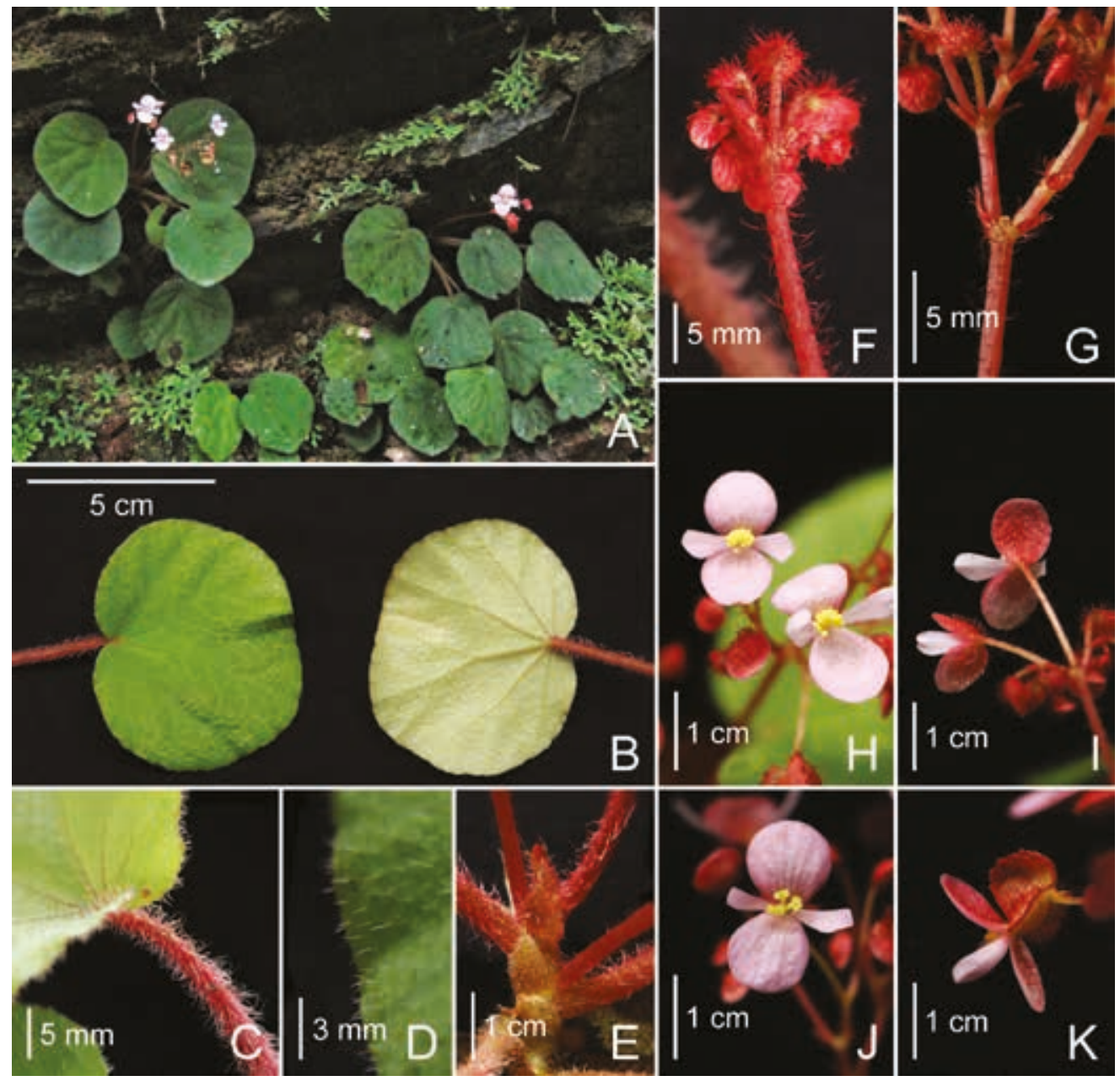

Fig. 3. Begonia obscuribracteata Y.P.Ang, Cabanillas \& M.N.Tamayo. A. Habitat and habit. B. Leaf adaxial and abaxial surfaces. C. Close-up of petiole showing vestiture. D. Close up of leaf adaxial surface showing margins. E. Stipule. F. Emerging inflorescence, showing vestiture of panicle. G. Bracts. H. Staminate flower face view. I. Staminate flower back view. J. Pistillate flower face view. K. Pistillate flower side view showing ovary. (Photos: A, W. Cabanillas; B-K, Y.P. Ang)

Etymology. The epithet pertains to its miniscule and obscure bracts, a feature which is rather unique among Palawan Begonia species.

Provisional IUCN conservation assessment. There are only two known populations of Begonia obscuribracteata at Barangay San Jose De Joro and Barangay Santa Maria. Begonia obscuribracteata is not locally abundant at either site and occurs only near a body of water. There is an estimate of $<100$ mature individuals in total across the localities. Due to the unprotected status of the forest, the species is vulnerable to any 


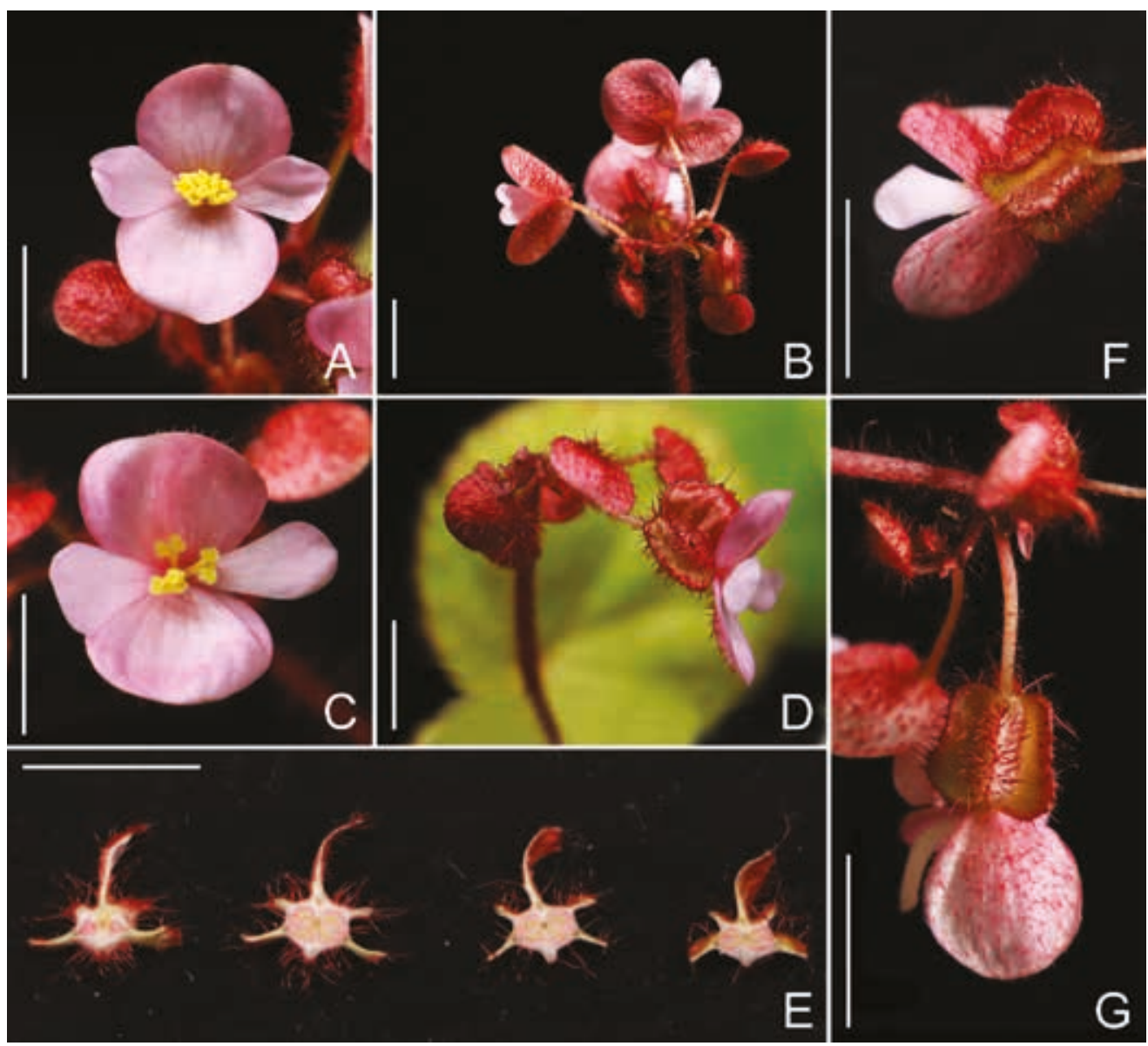

Fig. 4. Begonia obscuribracteata Y.P.Ang, Cabanillas \& M.N.Tamayo. A variant with broader tepals. A. Staminate flower face view. B. Staminate flowers back view. C. Pistillate flower face view. D. Pistillate flower side view. E. Ovary cross sections. F, G. Ovary's angled and bottom view respectively, showing the sixth ovary wing between the two lateral wings. Scale bars: 1 cm. (Photos: Y.P. Ang)

disturbance and rampant poaching. Following IUCN guidelines, we assess this species as Endangered (EN/D) (IUCN Standards and Petitions Committee, 2019), as there are $<250$ mature individuals across the populations.

Notes. Begonia obscuribracteata is the fourth known species in Begonia sect. Baryandra to possess at least five conspicuous ovary wings, the other three being $B$. cabanillasii, $B$. quinquealata, and B. suborbiculata. The advantage of a 5-winged ovary, if any, is not yet known. In the case of Begonia obscuribracteata, a ridge-like protrusion on the underside of the ovary (between the lateral wings) was noticed consistently across the populations, forming a sixth wing. Compared to the other 5 wings, the width of the sixth wing is much smaller and less conspicuous at c. $1 \mathrm{~mm}$ wide (vs. $2-5 \mathrm{~mm}$ 
wide on the other wings). The distribution of Begonia obscuribracteata is restricted and does not overlap with the other species with five ovary wings. Such is also seen for Begonia cabanillasii and B. quinquealata which are known to be local endemics. Variation in tepal shape and dimensions was observed within the population from the same location but the characteristics of the stipule, leaf vestiture, together with the bract dimensions, are key to identifying this species. For example, Fig. 4 A-D show a plant that has a slightly broader tepal. A key to the group of Begonia species bearing five or six conspicuous ovary wings is presented below.

1a. Rhizome internodes visibly elongated (reaching $3 \mathrm{~cm}$ or more) ....................... 2

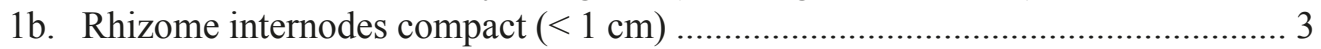

2a. Lamina broadly-ovate, thickly chartaceous, adaxially dense hirsute, apex acuminate B. quinquealata

2b. Lamina suborbicular, coriaceous, adaxially glabrous to subglabrous, apex rounded B. suborbiculata

3a. Lamina adaxially red to white hirsute; stipule triangular, shallowly keeled, abaxially tomentose, apex apiculate and c. $1 \mathrm{~mm}$ long .......... B. obscuribracteata

3b. Lamina adaxially white pilose; stipule lanceolate, strongly keeled, abaxially white pilose, apex aristate and 6-7 $\mathrm{mm}$ long B. cabanillasii

2. Begonia tandikan Pranada, L.Camangeg, Cabanillas \& Y.P.Ang, sp. nov. (§ Baryandra)

Begonia tandikan is most similar to $B$. beijnenii among the species of Begonia sect. Baryandra in its variegated lamina with a cordate base, 4-tepalled pistillate flower, bilocular ovary, and cucullate abaxial wing. However, Begonia tandikan differs in its broadly ovate lamina (vs subrhomboid in $B$. beijnenii) with villous upper surface (vs glabrous), villous petiole (vs tomentose), shorter and wider stipules $(6.5-8 \times 5-8$ $\mathrm{mm}$ vs 11-14 × 4-5 mm), and minutely pilose, rounded to obtuse bracts (vs glabrous, acute). - TYPE: Philippines, Palawan Island, City of Puerto Princesa, Barangay Iwahig, Balsahan river, c. 75 m, 27 July 2020, L.M. Camangeg \& W.P.Cabanillas PTI3 (holotype PNH; isotypes FEUH, PPC). (Fig. 5, 6)

Herb, lithophytic, monoecious, rhizomatous, perennial. Rhizome creeping, red, c. $2.5 \mathrm{~cm}$ long, 5-7 mm wide, pubescent, internodes 2-3 mm long. Stipules persistent, pale green to pale brown, widely ovate to triangular, $6.5-8 \times 5-8 \mathrm{~mm}$, herbaceous, glabrous, strongly keeled, keel with few hairs at the base and fimbriate on upper half, margins entire, aristate with tip 1-2 mm long. Leaves alternate, succulent; petiole terete, pale red, 2-9.5 cm long, 2-4 mm in diam., villous; lamina asymmetric, broadly ovate, c. $64 \times 52 \mathrm{~mm}$, broad side c. $35 \mathrm{~mm}$ wide, basal lobes cordate, apex obtuse, margins crenate to shallowly serrate, villous, adaxially green with prominent dark green spots at the interveins, sparsely villous, abaxially green or pale red, minutely 
villous on veins, venation basally 6-7 palmate, midrib distinct, primary and secondary veins prominent, secondary veins branching dichotomously or nearly so, reticulations faint. Inflorescences axillary, protandrous, dichasial cymes, 15-26.4 cm long, white pubescent on axes; peduncle dark red to light red, 14.6-22.4 cm long. Bracts boatshaped, pale green, deciduous, ovate, $3-5 \times 2-3 \mathrm{~mm}$, apex rounded to obtuse, margins entire, minutely pilose. Staminate flower: pedicel c. $12 \mathrm{~mm}$ long, pubescent; tepals 4, pale pink to white, outer 2 widely elliptic, 10-14 × 10-14 mm, apex rounded, glabrous, inner 2 obovate, 8-14 × 2-4 mm, apex retuse, glabrous; androecium zygomorphic, c. $4 \mathrm{~mm}$ across, stamens yellow, c. $35-37$, c. $2.5 \mathrm{~mm}$ long for lower stamens to c. $1.5 \mathrm{~mm}$ long in upper stamens, filaments slightly fused at base, anthers yellow, oblong to elliptic, 2-locular, dehiscing through laterally positioned slits, apex slightly extended, c. $1 \mathrm{~mm}$ long, connective extended. Pistillate flower: pedicel $30-35 \mathrm{~mm}$ long, pubescent; tepals 4, adaxially pink to light pink, abaxially white, outer 2 widely ovate to elliptic, $8-12 \times 2-5 \mathrm{~mm}$, apex rounded, glabrous, inner 2 obovate, $10-14 \times$ 3-5 mm, apex truncate, glabrous; ovary pale green to pink, body trigonous-ellipsoidal, locules 2, placenta bilamellate, c. $9 \times 5 \mathrm{~mm}$, pubescent when young, glabrescent, unequally 3-winged, abaxial wing much larger, lunate, markedly cucullate, 10-11 $\mathrm{mm}$ wide, rounded proximally, truncate distally, lateral wings equal, narrowly oblong, 2.5-3 mm wide, proximally rounded, distally bluntly truncate, margin entire; styles 3, slightly fused at the base, yellow, c. $3.5 \mathrm{~mm}$ long; stigma kidney-shaped, spirally twisted and papillose all around. Fruit pendent, 8-10 mm long, recurved with age; abaxial wing facing downwards, forming a splash cup, tepals deciduous, green to red when fresh, brown when mature, dehiscing along the attachment of the lateral wings; wings unequal, lateral wings equal, 8-10 $\mathrm{mm}$ long, 3-4 mm wide, abaxial wing 9.5-13 mm long, 9-12 mm wide.

Distribution and ecology. Begonia tandikan is only known from the type locality. The majority of the population is located at an elevation of c. $75 \mathrm{~m}$, thriving all year round due to a habitat with high humidity from the river and shade from the forest canopy. Some individuals located at slightly higher elevations are exposed to sunlight and lower humidity and shed their leaves during the dry season, leaving only the rhizome attached to the substrate. They revive during the wet season when there is sustained water necessary for their survival. Such adaptation to overcome this occasional dry spell is also observed in other Palawan endemic species such as Begonia gironellae C.I Peng et al. and B. woodii Merr. (Merrill, 1925: 478).

Phenology. Observed flowering and fruiting in the months of June and July.

Etymology. The epithet is inspired by the colourful plumage of the (male) Palawan peacock-pheasant (Polyplectron napoleonis), locally known as "tandikan", which resembles the variegation in the foliage of the new species. 


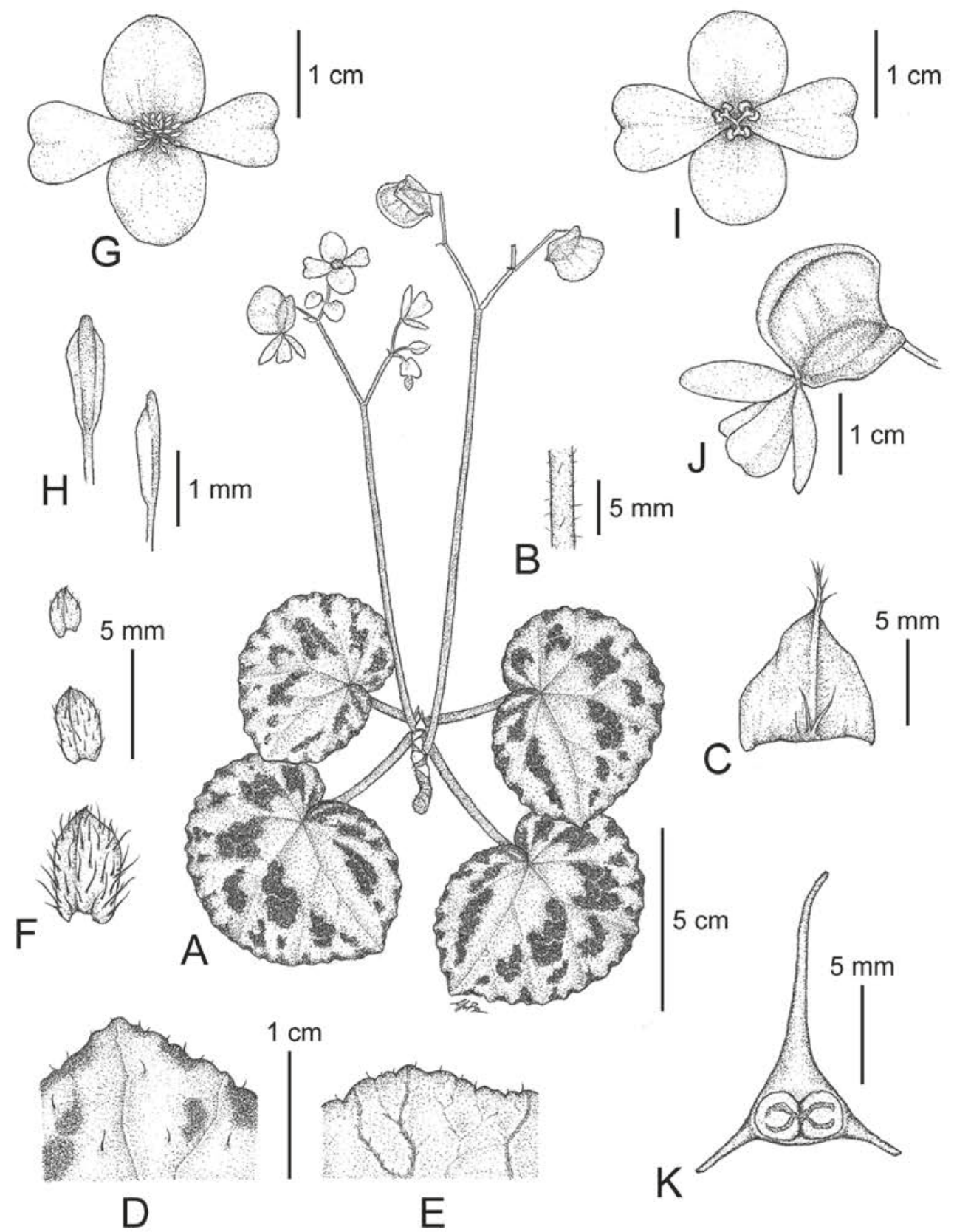

Fig. 5. Begonia tandikan Pranada, L.Camangeg, Cabanillas \& Y.P.Ang. A. Habit. B. Closeup of peduncle showing vestiture. C. Stipule abaxial view. D, E. Close up of leaf adaxial and abaxial surfaces respectively. F. Bracts. G. Staminate flower face view. H. Stamen top and side views. I. Pistillate flower face view. J. Pistillate flower side view, showing ovary. K. Ovary cross section. Drawn by Y.P. Ang. 


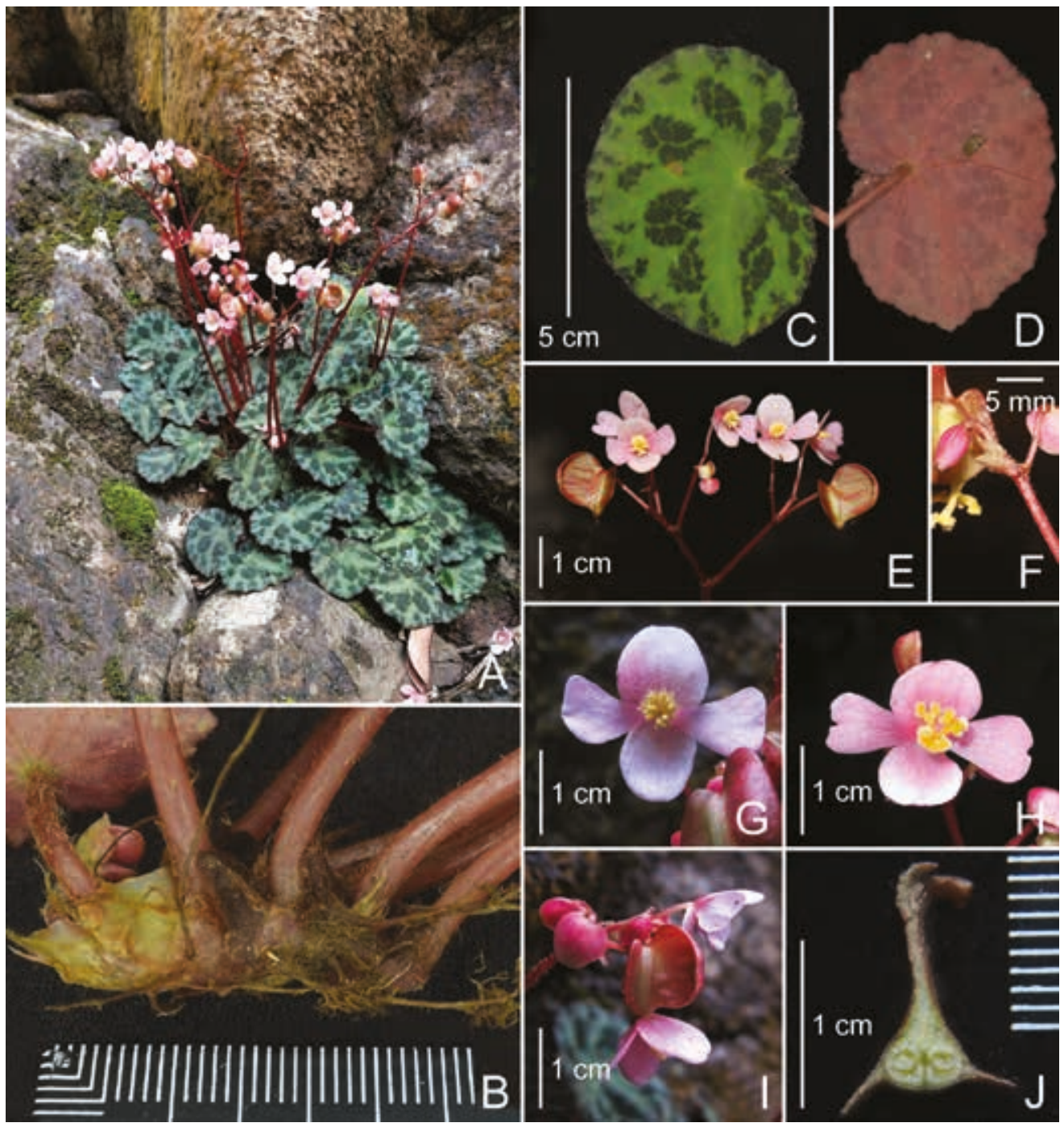

Fig. 6. Begonia tandikan Pranada, L.Camangeg, Cabanillas \& Y.P.Ang. A. Habitat and habit. B. Stipules. C, D. Leaf adaxial and abaxial surfaces respectively. E. Inflorescence. F. Bract. G. Staminate flower face view. H. Pistillate flower face view. I. Pistillate flower side view showing ovary. J. Ovary cross section. (Photos: A, W. Cabanillas; B-D, F, H, J, V.C. Mangussad; E, G, I, L.M. Camangeg)

Provisional IUCN conservation assessment. The known population of the new species is found in a lowland secondary forest which makes it an easy target for poachers. Although the Balsahan river is not located within a protected area, the site is still largely free from other disturbances. Human activities are limited as it is found within the vicinity of the Iwahig Penal Colony. In multiple assessments of the population at Balsahan river, a total of $<100$ mature individuals were found. Begonia tandikan 
has already largely been extirpated by poachers from the lower stretch of the river which is much more accessible. Under the IUCN Red List categories and criteria (IUCN Standards and Petitions Committee, 2019), the new species is assessed here as Critically Endangered (CR B2ab(v)), as the species is found only along a single river, has an area of occupancy (AOO) of $<10 \mathrm{~km}^{2}$, and there is an observed decline in the number of mature individuals.

Notes. Begonia tandikan is morphologically similar to a few other Begonia sect. Baryandra species from the island of Palawan by having 2-locular ovaries with a cucullate abaxial wing, such as $B$. acclivis Coyle, $B$. beijnenii, $B$. blancii M.Hughes \& C.I Peng, B. cabanillasii, B. gironellae, B. hughesii Rubite \& C.I Peng, B. quinquealata, B. suborbiculata and B. truncatifolia.

In overall morphology, Begonia tandikan closely resembles $B$. beijnenii, a species that is also endemic to the island of Palawan. The two species resemble each other in their rhizomatous habit and variegated lamina with a cordate base, 4-tepaled pistillate flower, and bilocular ovary with cucullate adaxial wing. Begonia tandikan can be readily distinguished by its broadly ovate lamina (vs subrhomboid in B. beijnenii) with villous upper surface (vs glabrous), and shorter and wider stipules $(6.5-8 \times 5-8$ $\mathrm{mm}$ vs $11-14 \times 4-5 \mathrm{~mm})$. The petioles are hairy in both species but the indumentum of Begonia tandikan is villous while that of $B$. beijnenii is tomentose. Additionally, one of the most distinguishing characters of Begonia tandikan is crenate to shallowly serrate margins in mature leaves. This character, however, is supposedly shared with Begonia beijnenii as the species is described as being 'shallowly crenate' in the protologue but the degree of crenation in $B$. tandikan is more pronounced than in $B$. beijnenii, which also appears to be more subentire than crenate. In the inflorescence, Begonia tandikan differs in its pubescent peduncle and pedicels (vs glabrescent or totally glabrous in $B$. beijnenii) and pilose bracts with rounded to obtuse apex (vs glabrous with acute apex) (Table 2).

ACKNOWLEDGEMENTS. Heartfelt gratitude is extended to The Palawan Council for Sustainable Development (PCSD) in Puerto Princesa, Palawan. Special thanks to the following: Indira Lacerna-Widmann, Chairperson of the Katala Foundation, Inc. including its staff, Brian Ong, Lemuel Pabico and Vicente Abendan. Leo Neil Mangussad, Ow Teck Song, Nelson Francisco and Leove Fontillas are also thanked for their assistance in documenting the species; the Philippine Taxonomic Initiative, Inc. (phtaxa.org) is thanked for bringing together the expertise of the researchers involved in this study. We are grateful to Dr. Ramon M. Docto, President of Palawan State University, and Prof. Imelda R. Lactuan, Dean of the College of Sciences, for their continued support in plant research and taxonomy, as well as to the Bgy. Iwahig Chairman Yolanda M. Evangelista, Chief Senior Superintendent Geraldo Aro of the Iwahig Penal Colony and Municipal Mayor Arnel Caabay of Dumaran. 


\section{References}

Ang, Y.P., Tandang, D.N., Agcaoili, J.M.M. \& Bustamante, R.A.A. (2020a). Begonia cabanillasii (section Baryandra, Begoniaceae), a new species from El Nido, Palawan, the Philippines. Phytotaxa 453(3): 244-254.

Ang, Y.P., Tandang, D.N., Rubite, R.R. \& Bustamante, R.A.A. (2020b). Begonia beijnenii (Begoniaceae, section Baryandra), a new species of Begonia from San Vicente, Palawan, the Philippines. Phytotaxa 455(3): 196-204.

Bustamante, R.A.A., Tandang, D.N., Pranada, M.A.K. \& Ang, Y.P. (2020). Begonia truncatifolia (Begoniaceae, section Baryandra), a new species from Palawan Island, the Philippines. Phytotaxa 458(3): 215-222.

De Candolle, A. (1859). Mémoire sur la famille des Bégoniacées. Ann. Sci. Nat., Bot., sér. 4, 11: 93-149.

Hughes, M., Peng, C-I., Lin, C-W., Rubite, R.R., Blanc, P. \& Chung, K-C. (2018). Chloroplast and nuclear DNA exchanges among Begonia sect. Baryandra species (Begoniaceae) from Palawan Island, Philippines, and descriptions of five new species. PLoS ONE 13(5): e0194877.

IUCN Standards and Petitions Committee (2019). Guidelines for Using the IUCN Red List Categories and Criteria. Version 14. Prepared by the Standards and Petitions Committee. Available from http://iucnredlist.org/documents/RedListGuidelines.pdf.

Merrill, E.D. (1911). The Philippine species of Begonia. Philipp. J. Sci., C 6(6): 369-406.

Merrill, E.D. (1925). Additions to our knowledge of Philippine flora, I. Philipp. J. Sci. 26(4): 447-496.

QGIS Development Team. (2020). QGIS Geographic Information System. Open Source Geospatial Foundation Project. Available from http://qgis.osgeo.org/. Accessed Jan. 2021.

Revel, N. (2006). The Philippines' "Last Frontier": new possibilities for Palawan. In: Sabouret, J-F. (ed.) The Asian Side of the World, Editorials on Asia and the Pacific 2002-2011, pp. 341-344. Paris: CNRS Editions.

Rubite, R.R., Hughes, M., Alejandro, G.J.D. \& Peng, C.-I. (2013). Recircumscription of Begonia sect. Baryandra (Begoniaceae): evidence from molecular data. Bot. Stud. 54: 38 .

Appendix 1. Begonia specimens examined for morphological comparison.

Begonia cabanillasii Y.P.Ang et al. PHILIPPINES: Palawan, El Nido, Barangay Maligaya, Biodiversity Assessment Management System (BAMS), c. 30 m, Dec 2018, RAAB 0001 (holotype PNH [PNH257805]; isotypes PPC, USTH).

Begonia beijnenii Y.P.Ang et al. PHILIPPINES: Palawan, Municipality of San Vicente, Barangay Bigaho, Bigaho Falls, c. 30 m, 19 Jan 2020, Camangeg, \& Bustamante 2 (holotype PNH [PNH258383]; isotypes PPC, USTH). 